\begin{tabular}{|l|l|l||}
\hline \multicolumn{2}{|c|}{ PublisherInfo } \\
\hline \hline PublisherName & $:$ & BioMed Central \\
\hline \hline PublisherLocation & $:$ & London \\
\hline \hline PublisherImprintName & $:$ & BioMed Central \\
\hline \hline
\end{tabular}

\title{
Who said what?
}

\begin{tabular}{|l|l|l||}
\hline \multicolumn{2}{|c|}{ ArticleInfo } \\
\hline \hline ArticleID & $:$ & 3709 \\
\hline \hline ArticleDOI & $:$ & $10.1186 /$ gb-spotlight-20000627-01 \\
\hline \hline ArticleCitationID & $:$ & spotlight-20000627-01 \\
\hline \hline ArticleSequenceNumber & $:$ & 146 \\
\hline \hline ArticleCategory & $:$ & Research news \\
\hline \hline ArticleFirstPage & $:$ & 1 \\
\hline \hline ArticleLastPage & $:$ & 3 \\
\hline \hline & & RegistrationDate : 2000-06-27 \\
ArticleHistory & $:$ & OnlineDate $\quad$ 2000-06-27 \\
\hline \hline ArticleCopyright & $:$ & BioMed Central Ltd2000 \\
\hline \hline ArticleGrants & $:$ & \\
\hline \hline ArticleContext & $:$ & 130591111 \\
\hline \hline
\end{tabular}


Here are a few of the key points made by the experts at yesterday's release of the draft human genome, 26 June, which took place via two separate press conferences, one in London and the other Washington, the latter involving a live video link between Tony Blair and Bill Clinton:

Francis Collins, human genome project [HGP] project manager, speaking from the White House yesterday afternoon: "We're not here to talk about a race. I want to say a big thankyou to Craig Venter [Chief Executive, Celera Genomics] for considering the opportunities [for working together with the HGP] we saw a month ago, and for comparing these two data sets after publication...".

Craig Venter [also at the White House]: now the issue is the interpretation of the genome... "and the mouse genome is a critical aspect of that. By layering the mouse over the human genome we expect to find most of the human genes. We already have one third of the mouse genome and will complete it by the end of the year....".

Craig Venter: Celera will publish its human genome data jointly with the HGP, and make it available to all. But unless your institution is a Celera subscriber "you won't have all the tools, or the mouse, or that add-on tools that the university subscribers will get".

Craig Venter: The US patent office had recently "raised the bar" on patenting the genome. "We agree the bar should be high" said Venter. "But remember that insulin is now available only because a long time ago Genetech and Eli Lilley patented the insulin gene." What should not be possible is to download a sequence and patent it blind. "There must be real, substantial evidence for utility", Venter said.

Francis Collins: "I agree with Craig. Patenting exists to encourage investment needed to bring a product to market." But a patenter should be able to demonstrate the gene, the pathway and the utility. "There's little disagreement" said Collins. "There are many opportunities for public/ private interactions." Examples were pharmacogenomics [studying variations in individual drug metabolisms, allowing fine-tuning of drug regimes] and the finding of 1000s of new drug targets.

Francis Collins: "We have to be sure the medical community becomes familiar with the HGP" so patients are given the benifit of all the medical opportunities that are now arising.

Francis Collins: "We have to be certain that we apply the same level of enthusiasm to the human and social issues... Genetic discrimination in insurance and the workplace is wrong". Every kind of genetic testing needs careful oversight.

Francis Collins: "We don't know the future. But let me quote St Exupery [author of The Little Prince]: 'Your goal is not to foresee the future but to enable it'".

Richard Durbin, Deputy Director of the Sanger Centre, and Head of Bioinformatics, speaking at the Wellcome Trust in London: "The human genome is too complex for any organization to have a monopoly of ideas or data". 
Richard Durbin: "The real information [in the genome] is in the detail. The most common gene families control other genes, and that's the most complex part".

David Bentley, Head of Human Genetics at the Sanger Centre, speaking in London: "A far greater problem [than sequencing the genome] is going to be to determine its significance". And a central postgenomic guide to that will be the use of single nucleotide polymorphisms, or SNPs. A public/ private "snips consortium" has been established to develop these, leading to the "bar-coding" of individuals by their single nucleotide differences from the "gold standard" genome. There are expected to be around three million such differences between individuals.

Craig Venter [in a separate remark in Washington]: "We already have six million polymorphisms...".

Mike Stratton, Head, Human Cancer Genome Project at the Sanger Centre [from London]: "I would be amazed if the treatment of cancer had not been transformed within 20 years, on the springboard of the Human Genome Project".

Lord Sainsbury, UK Science Minister, speaking in London: Regarding the roles of Celera and the HGP in the day's events: "The exciting thing is that this has been a joint announcement".

Lord Sainsbury on government responsibilities: the government is considering what needs to be done in the areas of patents, genetic testing, insurance and employment. "The establishment of the Human Genetics Commission shows we are ahead." [This body has met twice and produced a work plan. Readers might judge whether this is moving fast enough, given the pace of research.]

John Sulston, Director, Sanger Centre, speaking in London: "This must all become part of the democratic process; where I'd be concerned is if some of the information would be hidden".

Lord Sainsbury: "This is clearly a very complicated issue. But we agree we shouldn't patent raw data, but that real inventions should be patented."

John Sulston, asked how long it will take for biology to make sense of all this human genome data, understand the gene interactions and the downstream biochemistry: "we're talking about the whole of biology for the next century".

\section{References}

1. The White House statement (26 June)., [http://www.whitehouse.gov/WH/New/html/20000626.html]

2. The UK Human Genetics Commission., [http://www.hgc.gov.uk/]

This PDF file was created after publication. 